adverse conditions. Regulations and remedial measures are to be applied to the existing reserves, such as fencing, irrigation, parcelling out the land for occupational and agricultural use, as well as for rotational cropping and the like, by which it is hoped to introduce into native tribal custom a more economical use of the land. On the new reserves agricultural officers will be appointed to instruct and, if necessary, discipline the natives in modern methods of cultivation. The educational process is bound to be slow; and its success, as previous experiments have shown, will depend very largely upon the discretion with which new methods are welded into traditional custom.

\section{Physics and Society}

IN an address before the American Physical Society, Washington, on April 30, on Science and Society (J. Applied Phys., 8, 373 ; 1937), D. Sarnoff, president of the Radio Corporation of America, referred to the relation of the physicist to the farreaching social changes which follow his discoveries. The radio industry had its origin in the purely theoretical reasoning of Clerk Maxwell when in 1865 he advanced reasons for the existence of electromagnetic waves, although it was only in 1895 that Marconi gave the world a practical system of wireless telegraphy. Already 150 social effects have been traced directly to radio, and the end is not yet in sight. The major obstacles to the public introduction of television no longer lie in the field of research and engineering. The creation of a new art form has demanded new techniques of writing, direction and studio control. Here as elsewhere a scientific approach to the solution of human problems is required, and it is essential that mankind should learn how to use the assets which are the product of the scientific mind. Civilization depends for its advance upon our expanding knowledge of the social as well as of the physical sciences, for no society can solve its problems by intuition or rule of thumb. The advance of social science no less than that of physical science, calls for the creative imagination of a Newton and a Maxwell, an Edison and a Marconi. Obsolescence is a factor in social as well as in industrial machines.

THE social investigator must approach the problems of society in the clear light of an unbiased mind. $\mathrm{He}$ must collect and analyse facts, seek to fathom causes and establish principles, which he must always be willing to reconsider in the light of results. The permanent advance of society depends on our following procedure similar to that of the experienced surgeon. We must not be afraid to operate but must know when a less spectacular and safer treatment will be adequate. Social and economic facts must be investigated, verified and analysed, and the analysis and conclusions disseminated widely by popular education and debate. Industry is continually entering new realms of knowledge, and close understanding and co-operation are required between its leaders and the investigators in the universities.
Industry which has not learnt to employ scientific workers is doomed. Moreover, the problems created by technical science can only be solved by increasing and applying our knowledge of social science, and Mr. Sarnoff urged that the immediate goal of social science should be to achieve economic justice, peace and prosperity in a free democracy. Because that involves collective effort, it does not mean the suppression of individual liberty. Freedom of the individual is essential to the full expression of his creative faculties. Science and society depend upon each other, and when the basic lesson of science, that knowledge of the truth without fear or prejudice is indispensable to progress, is rejected, science-and society with it-goes backward instead of forward.

\section{Education and Training for the Oil Industry}

THE days when a liberal education and an effective personality were sufficient qualifications for entry into the petroleum industry are now over. As Prof. A. W. Nash pointed out in a paper presented to the Chemical Engineering Congress, World Power Conference, 1936 (J. Inst. Pet. Tech., 22; 1936), specialized vocational training is the only adequate background for technical men seeking employment in the industry. Moreover, this specialized training should be directed towards one particular branch of the industry, for example, geology, production, or refining, for in each of these branches different sciences are involved and correspondingly different technical knowledge is necessary for the solution of such problems as may be encountered. Before proceeding to specialize, however, the student must acquire a sound knowledge of the fundamental principles of physics, mathematics and chemistry, together with a working understanding of engineering and chemical engineering. Finally, having mastered these fundamentals and specialized in a particular branch of the industry, the technician should familiarize himself at least with the basic principles underlying the remaining branches of the industry, for in this way alone will he acquire a clear conception of any problem which may present itself from the point of view of the industry as a whole. Universities and other institutions which provide such training for the industry, are fully alive to the fact that, apart from the actual acquisition of knowledge, the student is there primarily to learn how to apply such knowledge, to interpret it and make use of it in the solution of new problems, and their curricula are adjusted accordingly. For the man who has made full use of any such training, there are openings in the industry unrivalled in any other from the points of view of scope and advancement.

\section{The Spread of the Sahara}

There is abundant evidence that early in the Quaternary age the Sahara was inhabited by man and that desiccation has since been proceeding. In so far as this process is one of climatic change, it is beyond the control of man; but there is also much evidence that the increase of desert conditions in both north and south is largely due to human interference. 